\title{
Direct radiative effect of the Russian wildfires and its impact on air temperature and atmospheric dynamics during August 2010
}

\author{
J. C. Péré ${ }^{1}$, B. Bessagnet ${ }^{2}$, M. Mallet ${ }^{3}$, F. Waquet ${ }^{1}$, I. Chiapello ${ }^{1}$, F. Minvielle ${ }^{1}$, V. Pont ${ }^{3}$, and L. Menut ${ }^{4}$ \\ ${ }^{1}$ Laboratoire d'Optique Atmosphérique, UMR8518, Université Lille 1, 59655 Villeneuve d'Ascq, France \\ ${ }^{2}$ Institut National de l'Environnement Industriel et des Risques, Parc Technologique Alata, 60550 Verneuil en Halatte, France \\ ${ }^{3}$ Laboratoire d'Aérologie, Observatoire Midi-Pyrénées, 14 Avenue Edouard Belin, 31400 Toulouse, France \\ ${ }^{4}$ Laboratoire de Météorologie Dynamique, Ecole Polytechnique, 91128 Palaiseau, France
}

Correspondence to: J. C. Péré (jean-christophe.pere@univ-lille1.fr)

Received: 15 May 2013 - Published in Atmos. Chem. Phys. Discuss.: 14 June 2013

Revised: 20 December 2013 - Accepted: 8 January 2014 - Published: 20 February 2014

\begin{abstract}
In this study, we investigate the shortwave aerosol direct radiative forcing (ADRF) and its feedback on air temperature and atmospheric dynamics during a major fire event that occurred in Russia during August 2010. The methodology is based on an offline coupling between the CHIMERE chemistry-transport and the Weather Research and Forecasting (WRF) models. First, simulations for the period 5-12 August 2010 have been evaluated by using AERONET (AErosol RObotic NETwork) and satellite measurements of the POLarization and Directionality of the Earth's Reflectance (POLDER) and the Cloud-Aerosol LIdar with Orthogonal Polarization (CALIOP) sensors. During this period, elevated POLDER aerosol optical thickness (AOT) is found over a large part of eastern Europe, with values above 2 (at $550 \mathrm{~nm}$ ) in the aerosol plume. According to CALIOP observations, particles remain confined to the first five kilometres of the atmospheric layer. Comparisons with satellite measurements show the ability of CHIMERE to reproduce the regional and vertical distribution of aerosols during their transport from the source region. Over Moscow, AERONET measurements indicate an important increase of AOT $(340 \mathrm{~nm})$ from $0.7 \mathrm{on}$ 5 August to 2-4 between 6 and 10 August when the aerosol plume was advected over the city. Particles are mainly observed in the fine size mode (radius in the range 0.2-0.4 $\mu \mathrm{m}$ ) and are characterized by elevated single-scattering albedo (SSA) (0.95-0.96 between 440 and $1020 \mathrm{~nm})$. Comparisons of simulations with AERONET measurements show that aerosol physical-optical properties (size distribution, AOT, SSA) have been well simulated over Moscow in terms of intensity and/or spectral dependence. Secondly, modelled
\end{abstract}

aerosol optical properties have been used as input in the radiative transfer code of WRF to evaluate their direct radiative impact. Simulations indicate a significant reduction of solar radiation at the ground (up to $80-150 \mathrm{~W} \mathrm{~m}^{-2}$ in diurnal averages over a large part of eastern Europe due to the presence of the aerosol plume. This ADRF causes an important reduction of the near-surface air temperature between 0.2 and $2.6^{\circ}$ on a regional scale. Moscow has been affected by the aerosol plume, especially between 6 and 10 August. During this period, aerosol causes a significant reduction of surface shortwave radiation (up to $70-84 \mathrm{~W} \mathrm{~m}^{-2}$ in diurnal averages) with a moderate part (20-30\%) due to solar absorption within the aerosol layer. The resulting feedbacks lead to a cooling of the air up to $1.6^{\circ}$ at the surface and $0.1^{\circ}$ at an altitude of 1500 $2000 \mathrm{~m}$ (in diurnal averages), that contribute to stabilize the atmospheric boundary layer (ABL). Indeed, a reduction of the ABL height of 13 to $65 \%$ has been simulated during daytime in presence of aerosols. This decrease is the result of a lower air entrainment as the vertical wind speed in the $\mathrm{ABL}$ is shown to be reduced by 5 to $80 \%$ (at midday) when the feedback of the ADRF is taken into account. However, the ADRF is shown to have a lower impact on the horizontal wind speed, suggesting that the dilution of particles would be mainly affected by the weakening of the ABL development and associated vertical entrainment. Indeed, CHIMERE simulations driven by the WRF meteorological fields including this ADRF feedback result in a large increase in the modelled near-surface $\mathrm{PM}_{10}$ concentrations (up to $99 \%$ ). This is due to their lower vertical dilution in the $\mathrm{ABL}$, which tend to 
reduce model biases with the ground $\mathrm{PM}_{10}$ values observed over Moscow during this specific period.

\section{Introduction}

It is now well recognized that biomass-burning aerosols can affect the earth's radiative balance by interacting with solar radiation. Their scattering (organic carbon) and absorbing (black and brown carbon) components can result in either a negative or a positive shortwave direct radiative forcing with some potential influence on the regional climate, especially during important fire activities (Forster et al., 2007). Recent studies dealt with the regional climate impact of aerosols over areas affected by biomass-burning episodes, such as southern and western Africa (Tummon et al., 2010; Malavelle et al., 2011), southern Amazonia (Zhang et al., 2009) or Indonesia (Ott et al., 2010) and highlighted the complexity of these impacts, which include changes in the atmospheric dynamics, precipitation regime and temperature gradient. Although the global fire activity is expected to increase in a future warmer climate (Moritz et al., 2012), the radiative effects of smoke aerosols on the atmosphere still remain uncertain (Carslaw et al., 2010), because of uncertainties in the amount of biomass-burning aerosols emitted, their transport and vertical distribution and the characterisation of their microphysical and optical properties.

During mid-July to mid-August 2010, the western part of Russia was affected by a strong heatwave episode favourable to the development of numerous wildfires (Witte et al., 2011). During this period, the release of smoke particles in the atmosphere associated with the accumulation of urban/industrial pollution largely contributed to high levels of aerosol concentrations over the Moscow region with daily $\mathrm{PM}_{10}$ values up to $700 \mu \mathrm{g} \mathrm{m}^{-3}$ (Konovalov et al., 2011). Recently, Chubarova et al. (2012) analysed the optical and radiative properties of particles during this specific fire event by using ground measurements at Moscow and Zvenigorod. They recorded elevated aerosol loadings over these two locations that induced an important direct radiative forcing that reached, on $7 \mathrm{Au}-$ gust 2010 , the instantaneous value $-167 \mathrm{~W} \mathrm{~m}^{-2}$ (at midday) at the top of the atmosphere, corresponding to an aerosol optical thickness of 6.4 at $500 \mathrm{~nm}$. This intense aerosol radiative forcing is expected to have some potential feedbacks on the regional climate. However, the climatic impact of aerosols on a regional scale during this intense biomass-burning episode has not yet been investigated.

In this context, the present modelling study aims at analysing the chemical and optical properties of aerosols as well as their shortwave direct radiative forcing and its feedback on air temperature and atmospheric dynamics during the peak of fire activity that occurred during the first part of August 2010 over eastern Europe. This work is based on an offline coupling between the CHIMERE chemistry- transport (Menut et al., 2013) and the WRF meteorological (Skamarock et al., 2001) models. An advantage of such a methodology is the use of two sophisticated mesoscale models with reasonable computation time. Section 2 describes the configuration of each model and the two models' offline coupling. Then, a description and an evaluation of the modelled microphysical and optical properties of particles are given (Sect. 3.1) and their impacts on shortwave solar fluxes, temperature profile and atmospheric dynamics are discussed (Sect. 3.2). Finally, we present our conclusions in Sect. 4.

\section{Methodology}

\subsection{Description of the CHIMERE model}

CHIMERE is a 3-D chemistry-transport model developed to simulate gaseous and particulate chemistry at regional scale (Bessagnet et al., 2004; Menut et al., 2013). In this study, the horizontal grid extends from $43.40^{\circ} \mathrm{N}$ to $63.20^{\circ} \mathrm{N}$ in latitude and from $18.70^{\circ} \mathrm{E}$ to $57.30^{\circ} \mathrm{E}$ in longitude, with a $30 \mathrm{~km}$ resolution. The vertical grid includes 15 levels from surface to $500 \mathrm{hPa}$ (altitude of about $6 \mathrm{~km}$ for this specific episode). The aerosol module takes into account nine species (sulphate, nitrate, ammonium, primary organic carbon (OC), black carbon (BC), secondary organic aerosols (SOA), sea salt, dust and water) distributed in eight bins ranging from $40 \mathrm{~nm}$ to $10 \mu \mathrm{m}$ (in diameter). Microphysical processes influencing aerosol population, such as nucleation of sulphuric acid, coagulation, adsorption/desorption, wet and dry deposition and scavenging, are taken into account. Particles can be scavenged either by coagulation with cloud droplets or by precipitating drops.

Anthropogenic emissions of gases and particles are estimated from EMEP (The European Monitoring and Evaluation Programme) inventory, whereas soil dust is produced within the domain according to the parametrization of Vautard et al. (2005). Carbonaceous emissions from fossil fuel and biofuel consumption are issued from the work of Junker and Liousse (2008). The formation of SOA is represented according to oxidation of relevant precursors and gas particle partitioning of the condensable oxidation products. This specific chemical scheme includes precursors of biogenic (such as isoprene, terpene, etc.) and anthropogenic (such as benzene, toluene, etc.) origin. Precursors emitted by vegetation are calculated using the Model of Emissions of Gases and Aerosols from Nature (MEGAN) scheme (Guenther et al., 2006). The gas-particle partitioning formulation of Pun et al. (2006) has been adapted to the SOA formation mechanism implemented in CHIMERE (Bessagnet et al., 2009). The important release of aerosols and gases by wildfires that affected Russia during summer 2010 are taken into account according to the work of Kaiser et al. (2012). In their methodology, biomass-burning emissions are calculated with the Global Fire Assimilation System 
by assimilating fire radiative power observations from the Moderate Resolution Imaging Spectroradiometer (MODIS) spatial instrument. The combustion rate is evaluated with specific land-cover conversion factors and emission factors for 40 gaseous and aerosol species from the current literature are used. These fire emissions combined with the Monitoring Atmospheric Composition and Change aerosol model have been shown to well capture the Russian fire plume during summer 2010 (Kaiser et al., 2012).

A knowledge of the optical properties of particles is required in order to evaluate the particles' direct radiative impact. A description of the scheme designed to calculate aerosol optical properties from concentrations, size distribution and chemical composition simulated by CHIMERE is reported by Péré et al. (2010). In the present study, aerosol optical thickness (AOT), single-scattering albedo (SSA) and an asymmetry parameter, $(g)$, are evaluated using Mie theory for a core-shell aerosol mixing in which each particle is composed by a core of primary organics, black carbon and mineral dust surrounded by a shell of secondary species (sulphate, nitrate, ammonium, SOA), sea salt and water. This optical treatment has been shown to well reproduce aerosol optical properties compared to pure external or internally homogeneous mixing (Péré et al., 2009).

\subsection{Description of the WRF model and its offline coupling with CHIMERE}

The version 3.1 of WRF (Skamarock et al., 2001) has been used for a domain covering eastern Europe with the same horizontal resolution as CHIMERE ( $30 \mathrm{~km}$ ), and with 27 vertical levels (from $40 \mathrm{~m}$ to about $20 \mathrm{~km}$ ). The configuration, similar to that in Péré et al. (2011), includes the WRF singlemoment five-class scheme of Hong et al. (2006) for the microphysics module, the Kain-Fritsch cumulus parametrization (Kain, 2004), the NOAH land surface module of Chen and Dudhia (2001) and the Yonsei University planetary boundary layer scheme (Hong et al., 2006; Hong, 2007). It should be noted that interactions between aerosols and clouds (such as activation of particles in cloud condensation nuclei) are not represented in this configuration of WRF. Within the atmosphere, radiation responds to clouds and water vapour distribution, carbon dioxide, ozone and trace gases as well as to the presence of aerosols through an offline coupling with the CHIMERE model. For calculation of shortwave radiation, the Goddard model (Chou and Suarez, 1994), with 11 spectral bands from 0.2 to $6 \mu \mathrm{m}$, is used. Previous studies that evaluated the Goddard shortwave radiative transfer simulations with solar measurements have demonstrated their skills to simulate surface visible radiation, especially under particulate pollution conditions (Fast et al., 2006; Mashayekhi et al., 2009; Péré et al., 2011). For long-wave radiation, the Rapid Radiative Transfer model (RRTM) (Mlawer et al., 1997), with 16 spectral bands from 6 to $1000 \mu \mathrm{m}$, has been chosen. It should be noted that aerosol impacts on long-wave radiation are not taken into account in RRTM in this version of WRF. This limitation should have a low influence on the estimation of the aerosol direct radiative forcing (ADRF), since interaction of fine particles (such as biomass-burning aerosols) with long-wave radiation is shown to be small (Ramanathan and Feng, 2009).

In this study, an offline and one-way coupling between CHIMERE and WRF has been performed. A detailed description and evaluation of this methodology can be found in Péré et al. (2011). Meteorological input parameters required by CHIMERE such as 3-D wind, air temperature or relative humidity are provided by WRF. Secondly, aerosol optical properties (AOT, SSA and $g$ ) are simulated using CHIMERE for an aerosol core-shell mixing. Finally, meteorological simulations are performed using aerosol optical properties as inputs in the WRF radiative transfer module. Here we focus our study on the impact of fine aerosols $(10 \mathrm{~nm} \leq$ radius $\leq 5 \mu \mathrm{m})$ on shortwave solar radiation. To reduce computing time, aerosol optical properties are first calculated at four wavelengths $(0.3,0.4,0.6$ and $0.99 \mu \mathrm{m})$, and then interpolated on the shortwave radiation bands $(0.2-6 \mu \mathrm{m})$ of the WRF radiative transfer module. The wavelength-dependent refractive indexes of each chemical species used to perform Mie calculations are reported in Table 1. AOT, SSA and $g$ are estimated for the 15 vertical layers of the CHIMERE model ranging from $40 \mathrm{~m}$ to about $6 \mathrm{~km}$ above ground level. For higher altitude, a climatology of optical properties for the free troposphere and the stratosphere (Hess et al., 1998) has been used (Table 2). To estimate the shortwave ADRF and its feedback on air temperature and atmospheric dynamics, two simulations have been performed for the period 5-12 August 2010: one including the ADRF and the other without. For these simulations, a spin-up period of one month has been used. It should be noted that this methodology enables only the investigation of climate feedbacks due to the ADRF. The indirect effect is not treated in the present study, as it would require a complete online and two-way coupling between WRF and CHIMERE. Déandreis et al. (2012) have evaluated the impact of coupling a meteorological model to a chemistry model for radiative forcing studies. Their results show a similar ADRF estimation between the offline and online coupling approaches.

\section{Results and discussions}

\subsection{Evaluation of the modelled aerosol optical properties}

Simulations of aerosol properties during this specific episode have been evaluated with POLDER, CALIOP (CloudAerosol LIdar with Orthogonal Polarization) and AERONET (AErosol RObotic NETwork) observations. POLDER is on board the PARASOL satellite of the A-Train constellation launched in December 2004. This sensor is a 

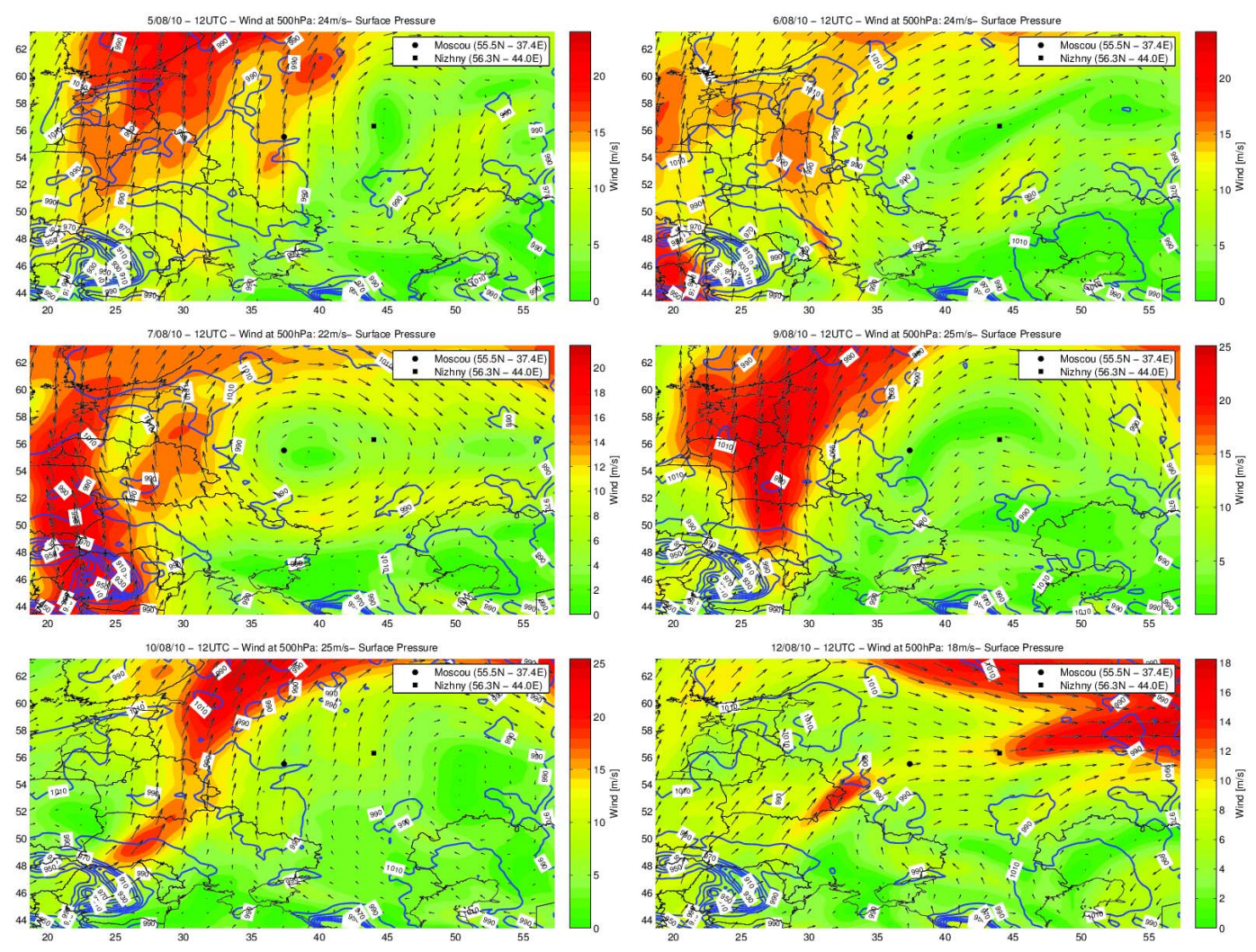

Fig. 1a. Surface pressure (blue lines) and $500 \mathrm{hPa}$ wind (black arrows and colour scale) at midday, simulated by WRF (without the ADRF feedback) during the studied period. The observatory stations of Moscow and Nizhny Novgorod are indicated.

Table 1. Wavelength-dependent complex refractive index of each chemical species used to perform optical calculation. $n$ and $k$ are, respectively, the real and imaginary parts of the complex refractive index.

\begin{tabular}{lrr}
\hline Species & \multicolumn{2}{c}{ Complex refractive index $(n-i k)$} \\
\hline & $300-400 \mathrm{~nm}$ & $600-999 \mathrm{~nm}$ \\
Nitrate $^{\mathrm{a}}$ & $1.53-i 0.006$ & $1.53-i 0.006$ \\
Ammonium $^{\mathrm{b}}$ & $1.52-i 0.0005$ & $1.52-i 0.0005$ \\
Sulphate $^{\mathrm{b}}$ & $1.44-i 10^{-8}$ & $1.43-i 2.6 \times 10^{-8}$ \\
OC $^{\mathrm{b}}$ & $1.45-i 0.001$ & $1.45-i 0.001$ \\
BC $^{\mathrm{c}}$ & $1.87-i 0.569$ & $1.87-i 0.569$ \\
SOA $^{\mathrm{b}}$ & $1.45-i 0.001$ & $1.45-i 0.001$ \\
Sea salt $^{\mathrm{b}}$ & $1.45-i 0.0056$ & $1.45-i 5 \times 10^{-5}$ \\
Dust $^{\mathrm{b}}$ & $1.52-i 0.008$ & $1.51-i 0.008$ \\
Water $^{\mathrm{b}}$ & $1.34-i 2 \times 10^{-9}$ & $1.33-i 3.4 \times 10^{-8}$ \\
\hline
\end{tabular}

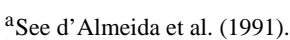

bSee Krekov (1993).

${ }^{\mathrm{c}} \mathrm{See}$ Marley et al. (2001)

wide-field-of-view imaging radiometer providing spectral, directional and polarized radiance measurements over land and ocean for visible wavelengths with an overpass time around 10:30 LT over Europe. In this study, level 2 cloudfree AOT data at $550 \mathrm{~nm}$ with a $18 \mathrm{~km}$ horizontal resolution and corresponding to fine aerosols (radius less than $0.3 \mu \mathrm{m}$ ) have been used (Deuzé et al., 2001; Tanré et al., 2011). The CALIOP instrument, on board the CALIPSO satellite of the A-Train constellation since April 2006, is an elastic backscatter lidar providing the vertical distribution of aerosols and clouds. Here, we use the level 2 product of the aerosol extinction coefficient (at $532 \mathrm{~nm}$ ) with a resolution of $330 \mathrm{~m}$ in the horizontal and $30 \mathrm{~m}$ in the vertical up to the middle troposphere (Winker et al., 2009). The AERONET network is constituted by sunphotometer instruments measuring a large number of parameters that characterize aerosol properties such as AOT, SSA, an asymmetry parameter, refractive index and volume size distribution - for the whole atmospheric column (Holben et al., 1998). Level 2 (cloud-free and manually checked) data at $340,440,675,870$ and $1020 \mathrm{~nm}$ for the station of Moscow $\left(37.30^{\circ} \mathrm{E}\right.$ and $55.42^{\circ} \mathrm{N}$, see Fig. 1) have been used. The uncertainties in AERONET measurements are \pm 0.01 for AOT and \pm 0.03 for SSA when AOT $(440 \mathrm{~nm}$ ) is larger than 0.2 (Dubovik et al., 2000).

The meteorological conditions over eastern Europe during the first part of August 2010 were characterized by persistent dry conditions and high temperatures favourable to the development of intensive wildfires reaching a maximum during the second week of the month (Witte et al., 2011). Between 5 and 11 August, an important anticyclonic system was 
Table 2. Climatology of aerosol optical properties for the free troposphere and the stratosphere issued from Hess et al. (1998).

\begin{tabular}{lrrrrrrrr}
\hline & \multicolumn{3}{c}{ Free troposphere $(6-12 \mathrm{~km})$} & \multicolumn{3}{c}{ Stratosphere $(12-20 \mathrm{~km})$} \\
\hline & $0.3 \mu \mathrm{m}$ & $0.4 \mu \mathrm{m}$ & $0.6 \mu \mathrm{m}$ & $0.99 \mu \mathrm{m}$ & $0.3 \mu \mathrm{m}$ & $0.4 \mu \mathrm{m}$ & $0.6 \mu \mathrm{m}$ & $0.99 \mu \mathrm{m}$ \\
AOT & 0.025 & 0.019 & 0.011 & 0.006 & 0.010 & 0.007 & 0.005 & 0.001 \\
SSA & 0.94 & 0.94 & 0.94 & 0.94 & 1 & 1 & 1 & 1 \\
$g$ & 0.7 & 0.7 & 0.7 & 0.7 & 0.7 & 0.7 & 0.7 & 0.7 \\
\hline
\end{tabular}

present in central Russia (Fig. 1a), which induced an air mass re-circulation favourable to the accumulation of smoke and urban/industrial particles. The end of the period (12 August) showed a shift in the circulation pattern and the flux became more zonal. The exceptional nature of this specific episode in terms of particulate pollution is shown in Fig. 1b with the spatial distribution of the AOT retrieved by the POLDER sensor (at $550 \mathrm{~nm}$ ) and modelled by CHIMERE (at $400 \mathrm{~nm}$ ) over eastern Europe from 5 to 12 August 2010 (no POLDER data are available for the 8 and 11 August 2010). Due to cloud contamination, large areas with no POLDER measurements (white pixels) are present during the period. The POLDER cloud-screen algorithm (Bréon and Colzy, 1999) is sometimes too stringent but ensures that the retrieved aerosol properties are not biased by the presence of cloudy structures potentially embedded in the aerosol plume. The satellite observations clearly illustrate both the wide spatial extent and the intensity of the aerosol plume with AOT values (at $550 \mathrm{~nm}$ ) above 1 over large areas. AOT $(550 \mathrm{~nm})$ peaks above 2 are shown as the aerosol plume was transported in an anticyclonic flow from the source region (east of Moscow) to Moscow (6-7 August), towards the north (on 9 August) and back to the east on 10-12 August. Performances of the model in simulating the AOT spatial features are discussed in terms of normalized mean bias (NMB, in \%) and spatial correlation (Corr.) between CHIMERE and POLDER AOT. Results are presented in Table 3. Except for the 12 August, the model is able to reproduce the variation of the aerosol optical thickness due to the transport of the aerosol plume, as shown by the good spatial correlation between POLDER and CHIMERE AOT $(R=0.67-0.77)$. Moreover, a general agreement is found for the AOT intensity, with small biases $(-10 \% \leq \mathrm{NMB} \leq 23 \%$, between 5 and 11 August); this indicates a good estimation of vertically integrated particles loading. However, performances of CHIMERE are less satisfactory for 12 August; there is a low correlation $(R=0.21)$ and large biases (NMB $=130 \%$, see Table 3$)$, which can be explained by the presence of elevated POLDER AOT values $(0.8-1.2$ at $550 \mathrm{~nm})$ at the eastern boundary of the domain that are not reproduced by the model $(0.1-0.2$ at $400 \mathrm{~nm})$. Other minor disagreements between simulations and observations can be noticed, such as some local AOT underestimations within the advected plume for 6 and 10 August or some overestimations near the source region for 5, 10 and 12 August. These AOT biases may lead locally to under- or overestimate the intensity of the aerosol direct radiative forcing and its potential feedback on the atmosphere. The injection height of aerosols into the atmosphere is a key parameter controlling the transport and dilution of smoke particles. In our study, it is parametrized based on atmospheric conditions and fire characteristics (such as fire size and flaming intensity) retrieved from MODIS measurements, according to the methodology developed by Hodzic et al. (2007). This estimation, however, can be affected by uncertainties on satellite data. Empirical estimation of the fire injection height is commonly used in mesoscale chemistry-transport models and is generally shown to give a satisfactory representation of fire dynamics (Konovalov et al., 2011; Martins et al., 2012; Fu et al., 2012). Note that some alternative modelling approaches have been recently developed, in which the interaction of the atmosphere and the fire is fully resolved at a very fine scale (Filippi et al., 2009; Strada et al., 2012). Furthermore, new retrieval methods are under development with POLDER for retrieval of the aerosol optical thickness in cloudy scenes (Waquet et al., 2013) and of their properties (such as single-scattering albedo and size distribution) over cloud-free land scenes (Dubovik et al., 2011). Such new developments will be important both for a better evaluation and for further improvements (through data assimilation) of aerosol simulation by chemistry-transport model like CHIMERE. Figure 2 presents the vertical profile of the aerosol extinction coefficient (in $\mathrm{km}^{-1}$ ) retrieved by CALIOP (at $532 \mathrm{~nm}$ ) on and modelled by CHIMERE (at $400 \mathrm{~nm}$ ) for 9 August at midnight in the north of Moscow $\left(59.9^{\circ} \mathrm{N}, 37.6^{\circ} \mathrm{E}\right.$ ) located within the aerosol plume (see Fig. 1b). CALIOP measurements highlight that particles are confined at altitudes lower than $5 \mathrm{~km}$. There is a peak in the observed signal of $0.8-1.1 \mathrm{~km}^{-1}$ around an altitude of $0.8-$ $1 \mathrm{~km}$, which rapidly decreases until an altitude of $1.5 \mathrm{~km}$. Above, measured aerosol extinction remains in the range $0.1-0.35 \mathrm{~km}^{-1}$ until an altitude of about $5 \mathrm{~km}$, above which it becomes negligible. Except for a lack of CALIOP measurements below $0.6 \mathrm{~km}$, the model is within or close to the uncertainty range of observations except at 2 to $4 \mathrm{~km}$ where the model tends to greatly overestimate CALIOP values (model biases from 30 to $350 \%$ compared to observed median values). However, this part of the aerosol profile represents less than $30 \%$ of the total aerosol extinction, suggesting that model uncertainties on the extinction vertical distribution remain limited. As shown hereafter in Fig. 6a, the 


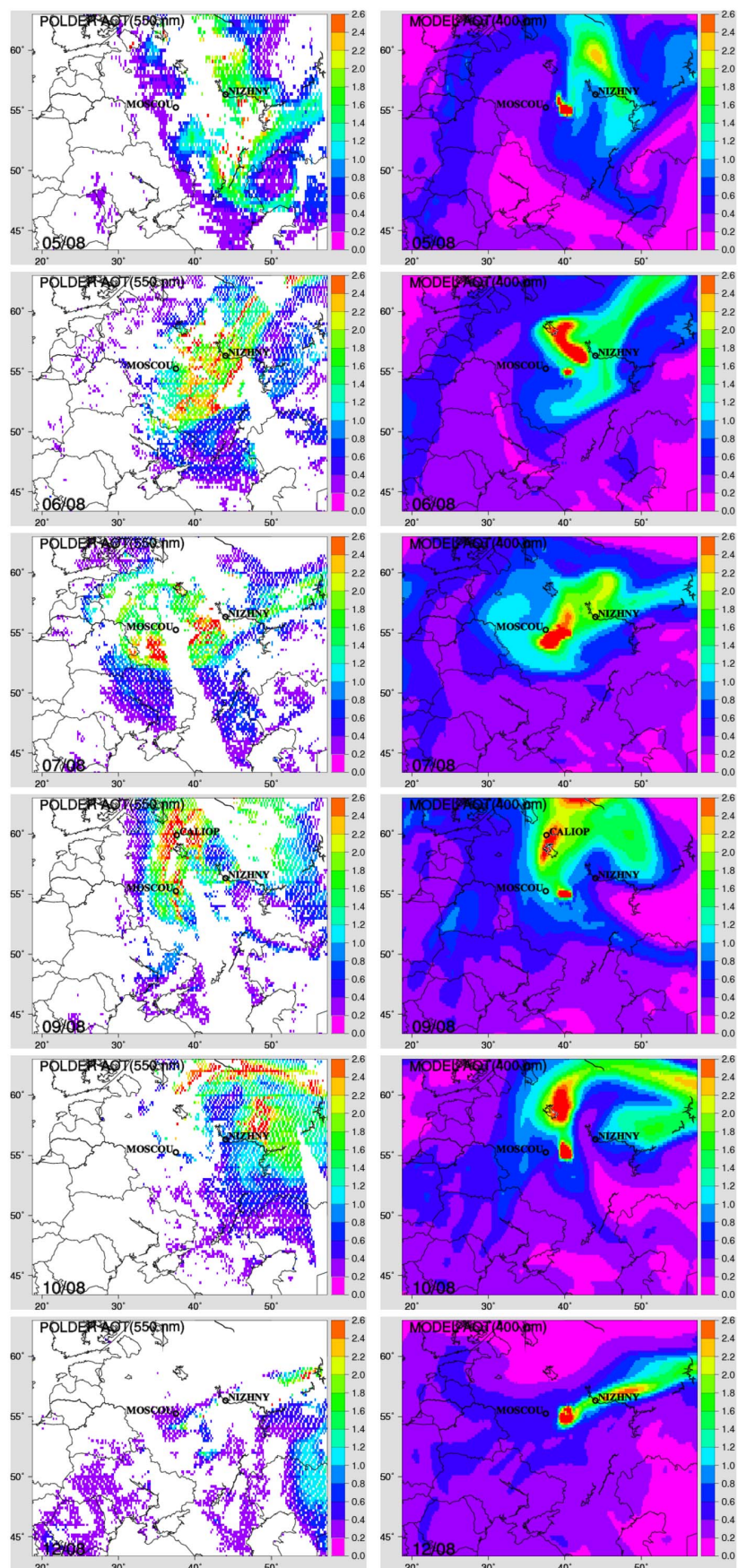

Fig. 1b. Geographic distribution of the AOT over eastern Europe from 5 to 12 August 2010 observed by the POLDER satellite sensor (at $550 \mathrm{~nm}$ ) and modelled by CHIMERE (at $400 \mathrm{~nm}$ ). The location of CALIOP measurements analysed in this study is indicated.

solar extinction efficiency of fine aerosols is larger at $400 \mathrm{~nm}$ than at $532 \mathrm{~nm}$, a difference that could partly explain this overestimation. Another reason could be that there are some uncertainties in modelling the release height and dilution of particles in the atmosphere, as previously discussed. Finally, Fig. 2 shows that the aerosol extinction is negligible above
Table 3. Statistical comparison between CHIMERE and POLDER aerosol optical thickness for each day of the studied period. NMB and Corr. are, respectively, the normalized mean bias (in \%) and the spatial correlation calculated as follows:

$$
\begin{aligned}
& \operatorname{NMB}(\%)=\frac{100}{N_{\text {pixels }}} \times \frac{\sum_{i}^{N_{\text {pixels }}}\left(P_{i}-O_{i}\right)}{\sum_{i}^{N_{\text {pixels }}} O_{i}}, \\
& \text { Corr. }=\frac{\sum_{i}^{N_{\text {pixels }}}\left(O_{i}-\bar{O}\right) \times\left(P_{i}-\bar{P}\right)}{\sqrt{\sum_{i}^{N_{\text {pixels }}}\left(O_{i}-\bar{O}\right)^{2}} \times \sqrt{\sum_{i}^{N_{\text {pixels }}}\left(P_{i}-\bar{P}\right)^{2}}},
\end{aligned}
$$

where $O_{i}$ and $P_{i}$ are the observation and the model prediction for the pixel $i$. $N_{\text {pixels }}$ is the total number of grid points for the domain. A linear interpolation has been used to make the correspondence between CHIMERE and POLDER pixels.

\begin{tabular}{lccc}
\hline Date & NMB (\%) & Corr. & $N_{\text {pixels }}$ \\
\hline 5 Aug & 10 & 0.73 & 6146 \\
6 Aug & 23 & 0.67 & 6182 \\
7 Aug & 20 & 0.73 & 5880 \\
9 Aug & 23 & 0.77 & 5036 \\
10 Aug & -10 & 0.75 & 5360 \\
12 Aug & 130 & 0.21 & 6011 \\
\hline
\end{tabular}

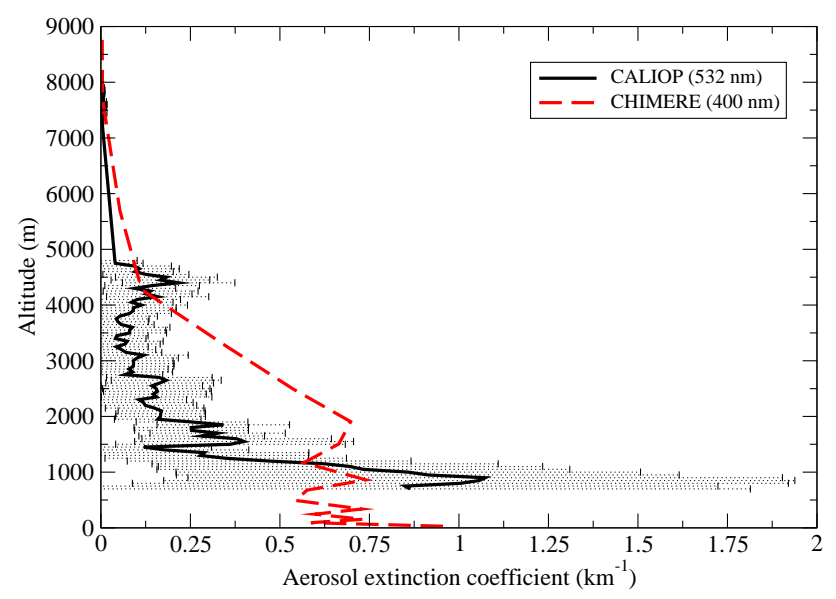

Fig. 2. Vertical profile of the aerosol extinction coefficient (in $\mathrm{km}^{-1}$ ) retrieved by CALIOP (at $532 \mathrm{~nm}$ ) and modelled by CHIMERE (at $400 \mathrm{~nm}$ ) during 9 August at midnight in the north of Moscow $\left(59.9^{\circ} \mathrm{N}, 37.6^{\circ} \mathrm{E}\right)$ located within the aerosol plume (see Fig. 1). Uncertainty of CALIOP measurements are indicated by error bars.

$5 \mathrm{~km}$, thus suggesting that the use of the climatology of Hess et al. (1998) for free tropospheric and stratospheric aerosols should have a low influence in the determination of the shortwave ADRF.

Particulate solar absorption is another important factor in determining the value and the sign of the direct radiative forcing of aerosols. The spatial distribution of the daily mean SSA (at $400 \mathrm{~nm}$ ) simulated between 5 and 12 August 2010 with corresponding AERONET observations (at $440 \mathrm{~nm}$ ) over Moscow (when available) are presented in Fig. 3. Elevated SSA between 0.93 and 0.97 (at $400 \mathrm{~nm}$ ) are simulated 


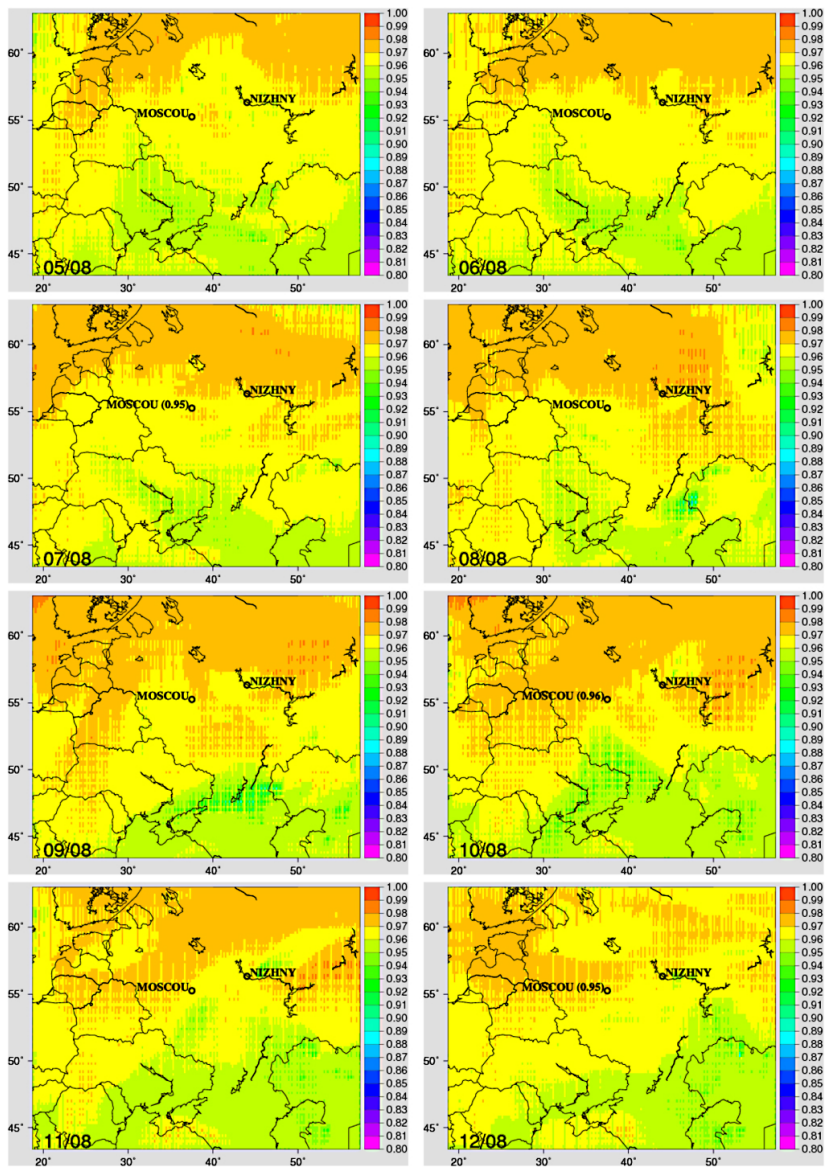

Fig. 3. Geographic distribution of the daily mean SSA over eastern Europe from 5 to 12 August 2010 modelled by CHIMERE (at $400 \mathrm{~nm}$ ) and measured at the Moscow AERONET station (at $440 \mathrm{~nm}$ ) during 7, 10 and 12 August (no data are available for the others days of the studied period).

throughout the period over a large part of eastern Europe, except for a small area in the south-eastern part of the domain where values decrease to $0.89-0.90$ during 8 and $9 \mathrm{Au}-$ gust 2010. It is interesting to note that no optical signature of the aerosol plume is found in terms of aerosol solar absorption compared to the AOT simulation (see Fig. 1b). For example, a quite constant SSA of $0.96-0.98$ (at $400 \mathrm{~nm}$ ) is modelled at Moscow before (5-6 August), during (7-10 August) and after (11-12 August) the advection of the aerosol plume over the city, denoting the predominance of scattering species over the period. Such a model behaviour is consistent with corresponding AERONET observations with retrieved SSA values of $0.95-0.96$ (at $440 \mathrm{~nm}$ ) during 7, 10 and $12 \mathrm{Au}-$ gust (Fig. 3). This temporal homogeneity of the SSA over the Moscow region can be explained by the analyse of the chemical composition of particles. Figure 4 shows the daily mean percent contribution of the different chemical species to the total $\mathrm{PM}_{10}$ concentration at the surface, modelled at Moscow for each day of the studied period. No clear changes in the
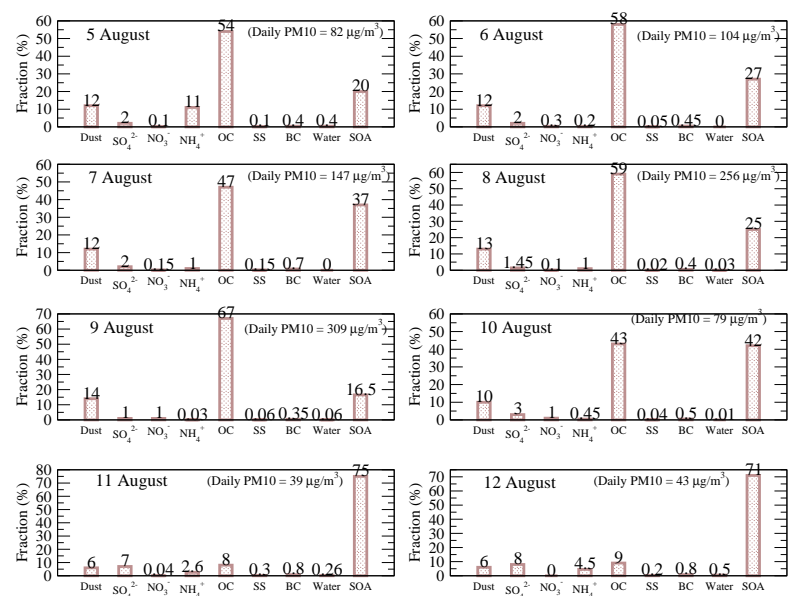

Fig. 4. Daily mean percent distribution of the different chemical species to the total $\mathrm{PM}_{10}$ concentrations at the surface modelled at Moscow for each day of the studied period (SS: sea salt). Daily mean values of the total $\mathrm{PM}_{10}$ surface concentrations (in $\mu \mathrm{g} \mathrm{m}^{-3}$ ) are indicated in parenthesis.

aerosol chemical composition are modelled when the aerosol plume overpasses Moscow (7-10 August) compared to the days before (5-6 August) and after (11-12 August), with a predominance of dust and primary (OC) and secondary (SOA) organic carbon, species which are mainly considered scattering in our simulations (see Table 1). The modelled dust, typically made up of resuspended wind-blown particles, is present in moderate quantity (fraction of 6-13\%), as its emission is favoured by dry soil conditions and fire dynamics. In terms of proportion, organics are the dominant part of the aerosol throughout the period with relative contributions of 8-67\% and $16.5-75 \%$ for, respectively, OC and SOA. OC is the major chemical species between 5 and 10 August (43$67 \%$ ) while SOA dominates at the end of the period (71$75 \%$ ) when the aerosol plume moves away from Moscow. These elevated proportions of organic carbon are the result of large OC and VOC (Volatil Organic Compounds) emissions (wildfires + anthropogenic) combined with an important photochemistry favoured by persistent sunny conditions. The other chemical species $\left(\mathrm{SO}_{4}^{-2}, \mathrm{NO}_{3}^{-}, \mathrm{NH}_{4}^{+}, \mathrm{BC}\right.$, sea salt, water content) are present in a lower fraction (0.02-8\%). The important contribution of scattering aerosols explains the elevated values of SSA modelled over Moscow throughout the period. Figure 4 shows that this intense biomass-burning episode is associated with elevated near-surface $\mathrm{PM}_{10}$ concentrations over Moscow with daily mean modelled values in the range $100-300 \mu \mathrm{g} \mathrm{m}^{-3}$ between 6 and 10 August. This estimation is nevertheless lower than the increase of ground particulate pollution observed over this area during the peak of fire event by Konovalov et al. (2011) $\left(100-700 \mu \mathrm{g} \mathrm{m}^{-3}\right.$ in daily average). 


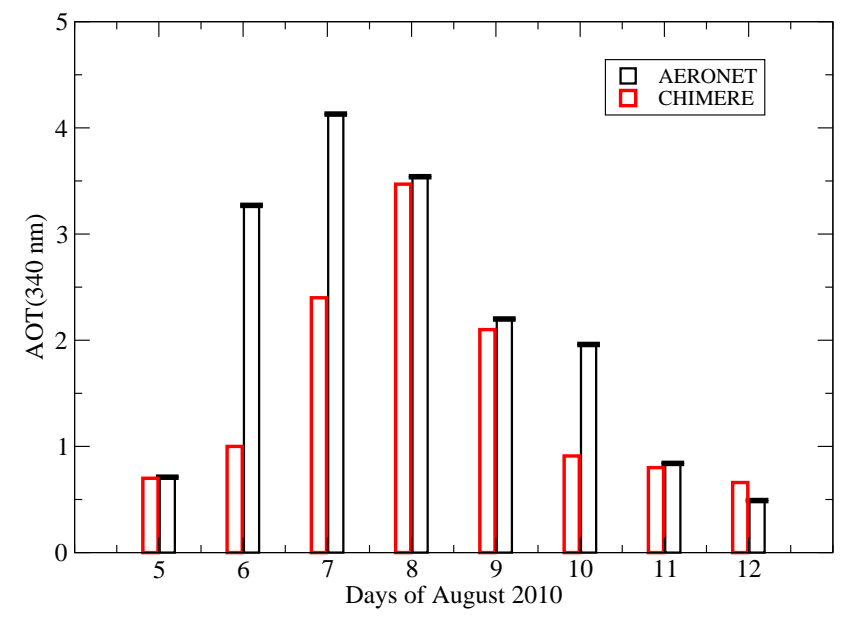

Fig. 5. Temporal evolution of the daily mean observed and modelled AOT (340 nm) over Moscow between 5 and 12 August 2010. Error bars represent the uncertainty range of observations $( \pm 0.01$; see Dubovik et al. (2000))

The advection of the aerosol plume over the Moscow region has been clearly detected in the routine measurements of AOT of the AERONET station. Figure 5 shows the temporal evolution of the daily mean AOT over Moscow retrieved by AERONET (at $340 \mathrm{~nm}$ ) and modelled by CHIMERE (at $300 \mathrm{~nm}$ ) between 5 and 12 August 2010. An important increase of AERONET AOT from a moderate value of 0.7 on 5 August to very elevated values of 2-4 between 6 and 10 August is observed when the intense aerosol plume overpasses Moscow. Then, moderate AOT (340 nm) of 0.5-0.8 are measured on 11-12 August when the plume moves towards the north and the east (see Fig. 1b). The model performs relatively well in simulating the temporal evolution of the observed AOT over this region, with biases ranging from $-40 \%$ to $30 \%$ throughout the period, except for the 6 and 10 August, for which CHIMERE underestimates observed values by a factor 2 to 3 due to some model deficiencies in simulating the transport of the aerosol plume over Moscow during these days (see Fig. 1b).

In a second step, we investigate the spectral evolution of the aerosol optical properties. Figure $6 \mathrm{a}$ compares the wavelength dependence of the AOT (averaged between 5 and 12 August) modelled by CHIMERE with corresponding observations at the Moscow AERONET station. Values of modelled and observed Angströ exponent are indicated in parentheses. On average over the period, the modelled AOT decreases from 1.60 at $300 \mathrm{~nm}$ to 0.28 at $1000 \mathrm{~nm}$, in accordance with photometric observations (biases less than $35 \%)$. This model behaviour is confirmed by the excellent estimation of the Angström exponent (1.45 for CHIMERE and 1.50 for AERONET), indicating that CHIMERE is able to reproduce the fine size mode of particles, as displayed in Fig. 6b. This figure presents the period-averaged column vol-
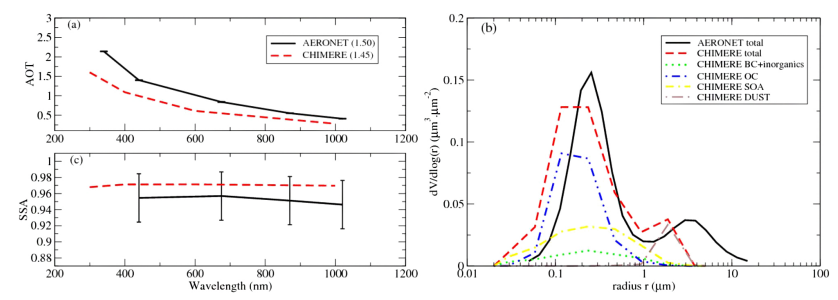

Fig. 6. Wavelength dependence of the (a) AOT and (c) SSA averaged over 5-12 August 2010 simulated by CHIMERE with corresponding AERONET observations over Moscow. Error bars represent the uncertainty range of observations for SSA $( \pm 0.03$, see Dubovik et al. (2000)) and AOT. Values of the observed and modelled Angström exponent are indicated in parenthesis. (b) Column volume size distribution retrieved by AERONET and modelled by CHIMERE for the total aerosol population and for each chemical species.

ume size distribution (in $\mu \mathrm{m}^{3} \mu \mathrm{m}^{-2}$ ) retrieved by AERONET over Moscow and modelled by CHIMERE for the total aerosol population and for each chemical components. For the total aerosol distribution, two modes in the accumulation $\left(r \simeq 0.1-0.3 \mu \mathrm{m}\right.$, peak at $\left.0.13 \mu \mathrm{m}^{3} \mu \mathrm{m}^{-2}\right)$ and coarse size range $\left(r \geq 1 \mu \mathrm{m}\right.$, peak at $\left.0.04 \mu \mathrm{m}^{3} \mu \mathrm{m}^{-2}\right)$ are modelled. This fits well with the fine mode AERONET retrieval $(r \simeq 0.2-$ $0.4 \mu \mathrm{m}$, peak at $0.16 \mu \mathrm{m}^{3} \mu \mathrm{m}^{-2}$ ), although the model simulates a higher volume concentration of very fine particles (for $r \leq 0.1 \mu \mathrm{m}$ ). In parallel, the coarse mode size distribution estimated by CHIMERE is quasi-non-existent compared to the observed AERONET one, as the model does not simulate particles with radii above $5 \mu \mathrm{m}$. However, the good model performance in simulating the AOT spectral dependence suggests that such an underestimation of coarse particles should have a moderate impact on the estimation of the shortwave ADRF over Moscow. It should be noted from Fig. $6 \mathrm{~b}$ that scattering organic aerosols $(\mathrm{SOA}+\mathrm{BC})$ account for $89 \%$ of the fine mode of particles, while the contribution of absorbing black carbon is only $0.5 \%$. As a consequence, elevated SSA are simulated with a mean value of 0.97 along the 300-1000 $\mathrm{nm}$ spectral range (Fig. 6c). The low absorbing efficiency of particles associated with a weak spectral dependence are consistent with AERONET observations with values of $0.95-0.96$ between $440 \mathrm{~nm}$ and $1020 \mathrm{~nm}$. Such aerosol scattering characteristics have been shown to be typical of intense fire conditions previously encountered over Russia (Chubarova et al., 2012).

\subsection{Direct radiative effect of the aerosol plume and its feedback on air temperature and atmospheric dynamics}

Simulated spectral AOT, SSA and $g$ are used to evaluate the impact of particles on shortwave radiative fluxes. Results for the diurnal-averaged ADRF simulated at the ground $\left(\Delta F_{\mathrm{BOA}}\right)$ between 5 and 12 August 2010 over eastern Europe 


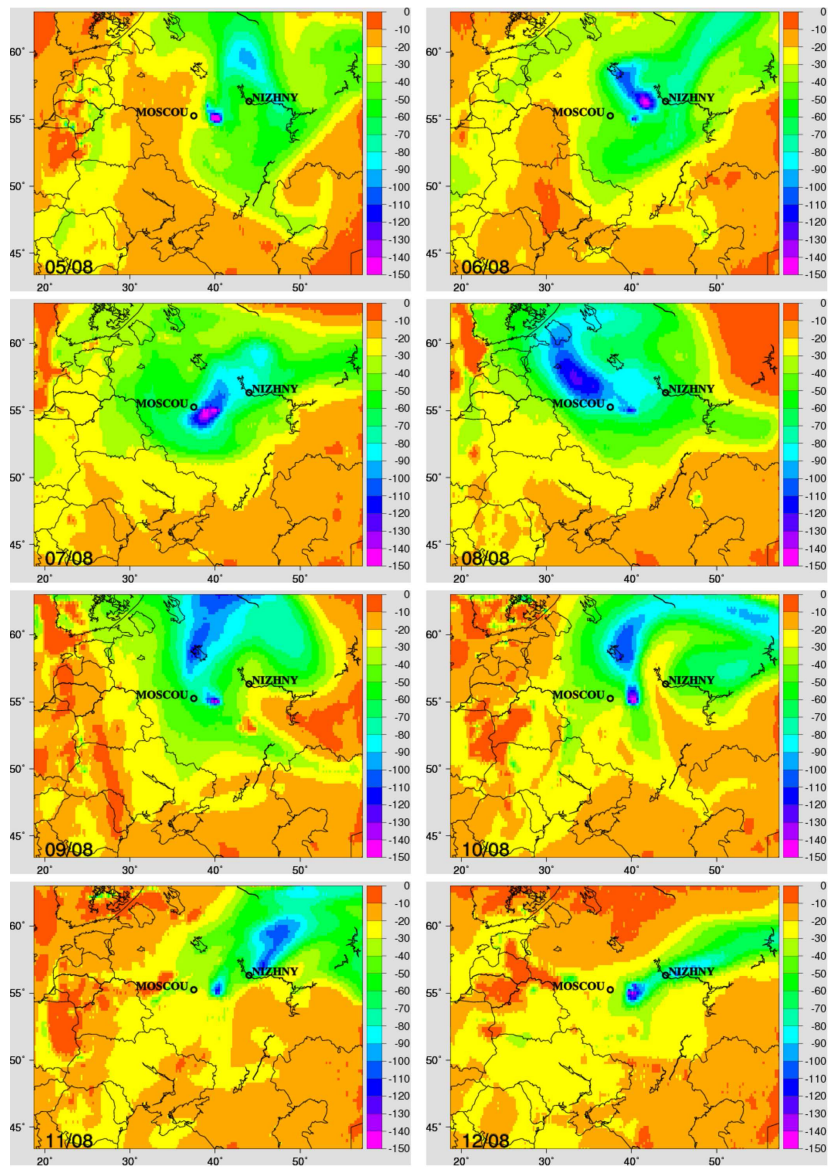

Fig. 7. Geographic distribution of the diurnal-averaged shortwave ADRF (in $\mathrm{W} \mathrm{m}^{-2}$ ) simulated at the surface for between 5 and 12 August 2010.

are displayed in Fig. 7. During the studied period, particles exert an important impact on the energy radiation budget. The shortwave ADRF at the surface is negative over the entire domain with values of -10 to $-150 \mathrm{~W} \mathrm{~m}^{-2}$ in diurnal averages. The surface ADRF spatial patterns closely follow the AOT spatial patterns. Hence, a maximum reduction of solar energy reaching the ground of $80-150 \mathrm{~W} \mathrm{~m}^{-2}$ is modelled along the aerosol plume transport. As a consequence, the Moscow region has been subjected to an important aerosol surface forcing, especially during the arrival of the aerosol plume between 6 and 10 August $\left(40-90 \mathrm{~W} \mathrm{~m}^{-2}\right.$ ), which lead to an important impact on the local air temperature profile and atmospheric dynamics. This point will be discussed hereafter in further detail. At a regional scale, Fig. 8 indicates that the impact of this shortwave ADRF on the simulated near-surface air temperature is non-negligible, with a reduction from 0.2 to $2.6^{\circ}$ (in diurnal averages) over a large part of the domain. Again, the maximum decrease of air temperature $\left(1.0-2.6^{\circ}\right)$ is shown to be associated with the aerosol plume transport. In Fig. 8, it is noteworthy that the aerosol impact on $2 \mathrm{~m}$ temperature is not always correlated to the re-

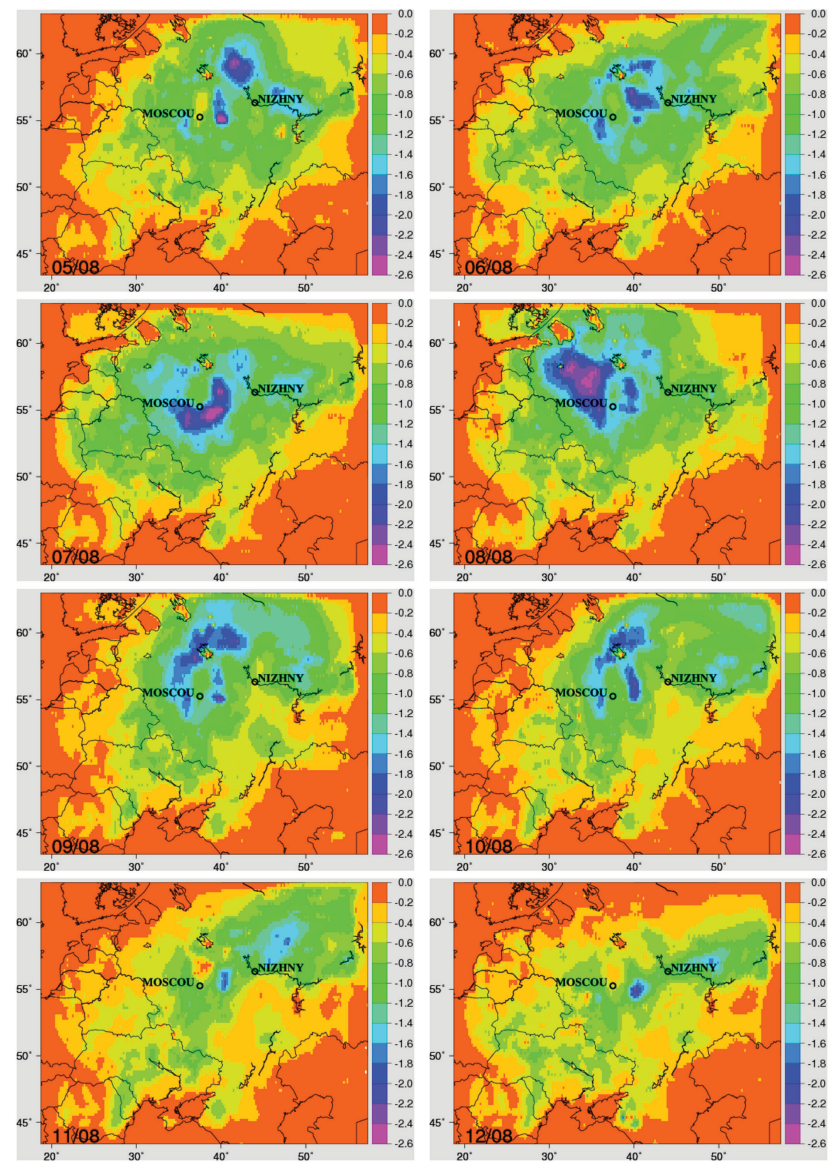

Fig. 8. Impact of the shortwave ADRF on the diurnal-averaged nearsurface air temperature (in degrees) simulated for between 5 and 12 August 2010.

spective pattern of the surface ADRF (Fig. 7). For example, the decrease of the near-surface air temperature over western Moscow during 8 August $\left(1.8-2.2^{\circ}\right)$ associated with an important surface ADRF $\left(90-110 \mathrm{~W} \mathrm{~m}^{-2}\right)$ is similar to the decrease of temperature simulated over the same area during 10 August $\left(1.6-2.0^{\circ}\right)$ associated with a much lower surface radiative forcing $\left(30-60 \mathrm{~W} \mathrm{~m}^{-2}\right)$. Near-surface air temperature mainly depends on incident solar flux, sensible and latent heat fluxes emitted by the terrestrial surface, aerosol solar absorption near the ground and atmospheric circulation. Hence, the resulting effect of these different mechanisms on the $2 \mathrm{~m}$ temperature can vary from one region to another, as previously shown over Europe by Zanis (2009) and Péré et al. (2011). In turn, the reduction of air temperature due to the presence of aerosols may disturb the atmospheric dynamics such as the development of the atmospheric boundary layer. To further investigate these points, we will now focus our study over the Moscow region, where the surface ADRF and its impact on near-surface air temperature are shown to be pronounced, especially during the aerosol plume overpass (see Figs. 7 and 8). In Fig. 9a the 
diurnal-averaged shortwave ADRF (in $\mathrm{W} \mathrm{m}^{-2}$ ) over Moscow simulated at the ground $\left(\triangle \mathrm{F}_{B O A}\right)$ and within the atmosphere ( $\Delta F_{\mathrm{ATM}}=$ difference between the ADRF at the top of the atmosphere and at surface), for each day of the studied period are reported. We can see that the presence of aerosols significantly reduces the solar energy reaching the surface, especially between 6 and 10 August, when the smoke plume is transported towards Moscow (modelled AOT $(340 \mathrm{~nm})=1-$ 3.5, see Fig. 5). The maximum reduction occurs on 7, 8 and 9 August when the smoke plume is at its maximum of intensity, with a diurnal mean of $\Delta F_{\mathrm{BOA}}$ of $65-85 \mathrm{~W} \mathrm{~m}^{-2}$, which represents a decrease of about 20-25\% (on average over daytime) of the total shortwave flux at the ground. Such values are comparable (although less pronounced) to the loss of surface shortwave irradiance $(30-40 \%$ for AOT $(500 \mathrm{~nm})=2-$ 4) inferred from radiative flux measurements over Moscow during this period (Chubarova et al., 2012). The difference may be due to the AOT underestimation, especially during the 7 August. Concerning the ADRF within the atmosphere $\left(\Delta F_{\mathrm{ATM}}\right)$ that represents the amount of solar radiation absorbed by particles in the atmospheric layer, modelled mean values vary from $5 \mathrm{~W} \mathrm{~m}^{-2}$ to $26 \mathrm{~W} \mathrm{~m}^{-2}$, and only account for about $20-30 \%$ of the total simulated ADRF. This moderate proportion of solar absorption by particles is the consequence of their very high scattering efficiency (modelled SSA of 0.97 between $300 \mathrm{~nm}$ and $1000 \mathrm{~nm}$, see Fig. 6c). As previously shown over the entire domain, this important ADRF over Moscow is found to have feedbacks on meteorological parameters such as air temperature. Figure $9 b-c$ present the temporal evolution of the $2 \mathrm{~m}$ temperature (averaged over daytime) simulated with and without aerosols along with corresponding observed values at (b) Moscow and (c) Nizhny Novgorod (located $400 \mathrm{~km}$ east of Moscow; see Fig. 1a). These results show that aerosols induce a nonnegligible decrease of the near-surface air temperature, between 0.5 to $1.6^{\circ} \mathrm{C}$ at Moscow and from 0.5 to $1.0^{\circ} \mathrm{C}$ at Nizhny. The highest reduction occurs when the ADRF is the most pronounced during 7, 8, 9 August and 6, 7, 8, 12 August for Moscow and Nizhny, respectively (see Fig. 7). Compared with observations, the modelled temperature over both sites tends to be overestimated throughout the period, especially when the feedback of the ADRF is not included in the simulation. This result is interesting, as WRF is usually known to have a cold bias during the summer season over Europe (Menut et al., 2012), which strengthens the assumption that the ADRF due to the intense aerosol plume could have a regional influence on the air temperature. Indeed, the presence of aerosols reduces the model biases compared to those of the simulation without aerosols. This ADRF feedback is shown to decrease discrepancies between model and observations from $2-9 \%$ to $0-5 \%$ for Moscow (Fig. 9b) and from 3-9\% to $0.5-6 \%$ for Nizhny (Fig. 9c). As illustrated in Fig. 9d, the feedback of the shortwave ADRF does not only occur near the surface but also in the boundary layer. For example, the aerosol cooling effect simulated over Moscow during $8 \mathrm{Au}-$ gust at midday is at a maximum near the ground $\left(0.8^{\circ} \mathrm{C}\right)$ and then gradually decreases along the boundary layer (becoming $0.42^{\circ} \mathrm{C}$ at an altitude of $2400 \mathrm{~m}$ ). Compared to observations, model biases are positive near the surface (as already shown in Fig. 9-b, c), negligible between $400 \mathrm{~m}$ and $1000 \mathrm{~m}$, and slightly negative (3-10\%) at higher altitude. It is interesting to note from Fig. 9d that such a vertical structure of air temperature difference between both simulations is favourable to a stabilizing effect in the atmospheric boundary layer (ABL). Indeed, it is clearly shown in Fig. 10a, which displays the temporal evolution of the ABL height during 8 August simulated with and without aerosols, that the radiative effect of particles reduces the development of the boundary layer. For example, a maximum development of 3250 and $3750 \mathrm{~m}$ is modelled at midday for, respectively, the simulation with and without aerosols. This result is comparable to the maximum ABL reduction of $800 \mathrm{~m}$ (for an AOT $(500 \mathrm{~nm})=4)$ simulated with the online WRF-CMAQ (Weather Research and Forecast-Community Multi-scale Air Quality) model during the June 2008 Californian wildfires (Wong et al., 2012). Using the online WRF/Chem-MADRID model, Zhang et al. (2013) modelled a respective change of $-40 \mathrm{~m}$ (on average for July 2001) corresponding to a mean AOT $(600 \mathrm{~nm})$ of 0.6 over the eastern part of Europe. Our simulations indicate that, during daytime, the decrease of the ABL height due to the feedback of the ADRF is between 13 and $65 \%$. As a consequence, the collapse of the ABL in presence of aerosols occurs one hour earlier (between 14 and $15 \mathrm{~h}$ ) compared to the simulation without aerosols (between 15 and $16 \mathrm{~h})$. Such weakening of the ABL development is the result of a lower air entrainment, as the vertical wind speed in the ABL is shown to be reduced by 5 to $80 \%$ (at midday) during 8 August when the feedback of the ADRF is taken into account (not shown). Concerning the horizontal dispersion capacity of particles, Fig. 10b indicates that the shortwave ADRF has a much lower impact on the horizontal wind speed. For example, a reduction of only $0.05-0.86 \mathrm{~m} \mathrm{~s}^{-1}$ (1$25 \%$ ) is simulated for 8 August, suggesting that the dilution of particles would be mainly affected by the weakening of the ABL development and associated vertical wind speed. Compared to observations, the model is shown to correctly reproduce the magnitude of the horizontal wind speed with biases comprised between $-10 \%$ and $24 \%$ and between $-8 \%$ and $35 \%$, respectively, for the simulation with and without aerosols (except for $18 \mathrm{~h}$, at which the discrepancy reaches $70 \%$ for both simulations).

In turn, this modification of the ABL development and vertical wind speed, due to the feedback of the ADRF, could have some potential consequences on the surface air quality. To investigate this point, we have used the WRF meteorological fields including the ADRF feedback as inputs in CHIMERE to re-perform the chemistry-transport simulation. Table 4 presents the averaged near-surface concentrations (in $\mu \mathrm{g} \mathrm{m}^{-3}$ ) of $\mathrm{PM}_{10}, \mathrm{BC}, \mathrm{OC}, \mathrm{SOA}$ and dust along with AOT $(340 \mathrm{~nm})$ modelled at Moscow for the 

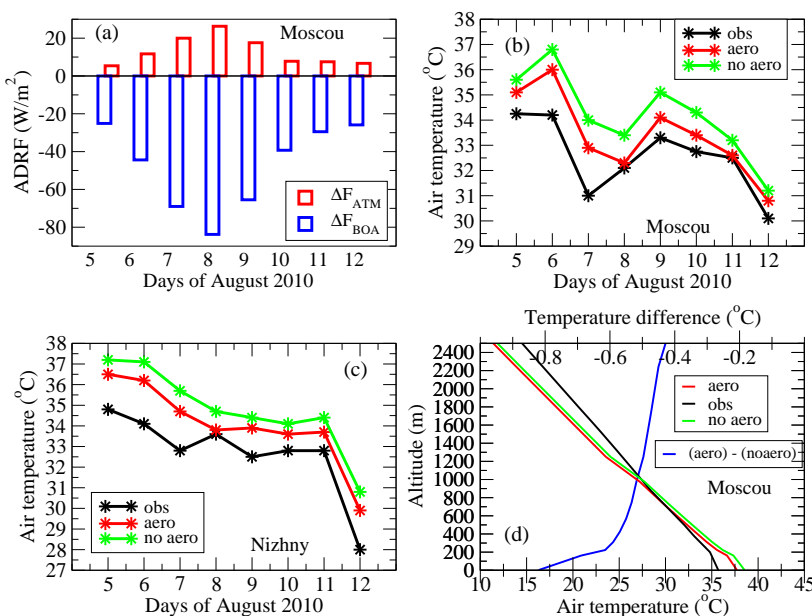

Fig. 9. (a) Diurnal-averaged shortwave aerosol direct radiative forcing (in $\mathrm{W} \mathrm{m}^{-2}$ ) over Moscow simulated at the surface $\left(\Delta F_{\mathrm{BOA}}\right)$ and within the atmosphere $\left(\Delta F_{\mathrm{ATM}}\right)$. Diurnal-averaged nearsurface air temperature (in ${ }^{\circ} \mathrm{C}$ ) simulated with and without aerosols and observed at the meteorological station of (b) Moscow Domodedov and (c) Nizhny Novgorod. (d) Vertical profiles of the diurnalaveraged air temperature (in degrees) for 8 August at midday, simulated with and without aerosols and observed at the Moscow meteorological station. Temperature differences between both simulations are indicated.
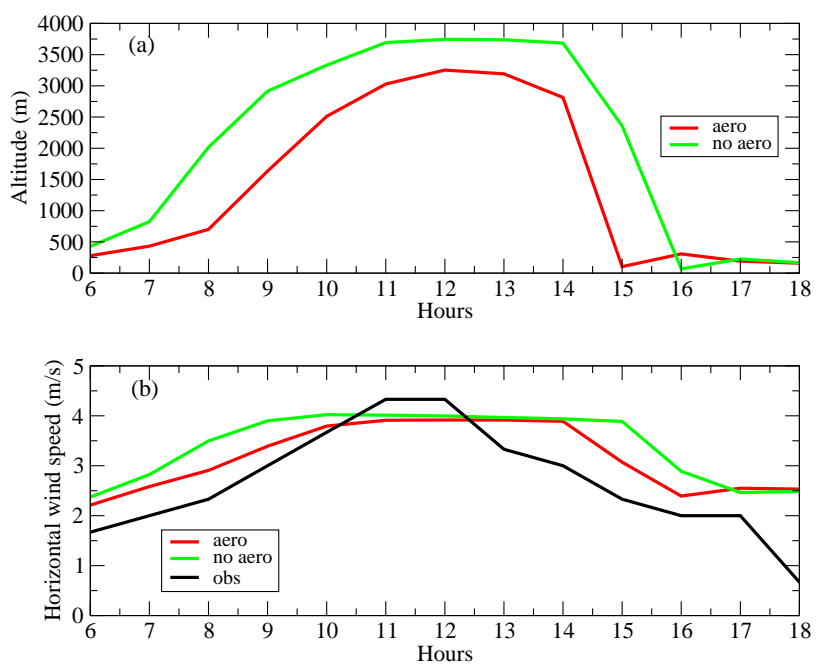

Fig. 10. (a) Temporal evolution of the atmospheric boundary layer (ABL) and (b) near-surface horizontal wind speed (in $\mathrm{m} \mathrm{s}^{-1}$ ) for 8 August, simulated with and without aerosols and measured at the Moscow meteorological station.

period 5-12August 2010, without (WO) and with (W) the ADRF feedback on the input meteorological fields. Percentage changes between the two configurations (W minus WO) are indicated in parenthesis. Results show small changes $(+1-9 \%)$ in the AOT $(340 \mathrm{~nm})$, indicating that the aerosol loading integrated over the atmospheric column is not sensi- tive to the modification of the atmospheric planetary boundary layer. However, a clear increase (of up to $99 \%$ ) of the near-surface $\mathrm{PM}_{10}$ concentrations is predicted, mainly as a result of the reduction of the ABL development, with modelled mean values of $90-530 \mu \mathrm{g} \mathrm{m}^{-3}$. Compared to the initial simulation $\left(\mathrm{PM}_{10}(\mathrm{WO})=80-300 \mu \mathrm{g} \mathrm{m}^{-3}\right)$, such values are closer to the ones measured over Moscow by Konovalov et al. (2011) during the peak of fire event (100-700 $\mu \mathrm{g} \mathrm{m}^{-3}$ ). It is interesting to note from Table 4 that the increase of primary aerosol species (BC, OC, dust) is more pronounced $(6-176 \%)$ than that of SOA $(0-11 \%)$, suggesting that secondary species are more sensitive to thermodynamic regime (through changes in air temperature and water vapour, for instance) than reduction of its vertical dilution. This specific point should be further investigated but is beyond the scope of this study.

\section{Conclusions}

\subsection{Summary and perspectives}

The main objectives of this work were to study the direct radiative forcings of aerosols during the peak of the 2010 Russian wildfires and their feedbacks on air temperature and atmospheric dynamics. We focused on the ADRF in the shortwave solar region as interactions of fine aerosols with longwave radiation are shown to be low. For such objectives, an offline coupling between the chemistry-transport model CHIMERE (associated with an aerosol optical module) and the Weather Research and Forecasting (WRF) model has been performed. To take into account the impact of aerosol solar extinction on the shortwave radiative fluxes, aerosol optical properties have been simulated using CHIMERE up to an altitude of $500 \mathrm{hPa}$ (a climatology has been used for higher altitudes) and then used as input in the WRF radiative transfer module.

First, simulations for the period 5-12 August 2010 have been evaluated with ground-based (AERONET) and satellite (POLDER, CALIOP) measurements. Comparison with POLDER data shows the ability of the model to reproduce the transport and the intensity of the aerosol plume with high spatial correlation $(R=0.67-0.77)$ and low biases $(-10 \% \leq \mathrm{NMB} \leq 23 \%)$, except for 12 August $(R=$ $0.21, \mathrm{NMB}=130 \%)$. A relatively consistent comparison between CALIOP and CHIMERE aerosol vertical profiles is present below $2 \mathrm{~km}$, where the concentration of particles is the largest. Above an altitude of $5 \mathrm{~km}$, the contribution of free tropospheric particles to the aerosol solar extinction is shown to be negligible. Over Moscow, observations indicated an important increase of AERONET AOT $(340 \mathrm{~nm})$ from 0.7 on 5 August to 2-4 between 6 and 10 August when the aerosol plume was transported over Moscow. The model performed relatively well in simulating the temporal evolution of the observed AOT with biases ranging from -40 to 
Table 4. Averaged near-surface concentrations (in $\mu \mathrm{g} \mathrm{m}^{-3}$ ) of $\mathrm{PM}_{10}$, BC, OC, SOA and dust along with AOT (340 nm) modelled for Moscow for the period 5-12 August 2010 without (WO) and with (W) the ADRF feedback on the input meteorological fields. Percentage changes between the two configurations (W minus WO) are indicated in parenthesis.

\begin{tabular}{|c|c|c|c|c|c|c|}
\hline $\begin{array}{l}\text { Day of } \\
\text { August } 2010\end{array}$ & $\begin{array}{r}\mathrm{PM}_{10} \\
\mathrm{WO} / \mathrm{W}(\%)\end{array}$ & $\begin{array}{r}\mathrm{BC} \\
\mathrm{WO} / \mathrm{W}(\%)\end{array}$ & $\begin{array}{r}\mathrm{OC} \\
\mathrm{WO} / \mathrm{W}(\%)\end{array}$ & $\begin{array}{r}\text { SOA } \\
\text { WO/W (\%) }\end{array}$ & $\begin{array}{r}\text { DUST } \\
\mathrm{WO} / \mathrm{W}(\%)\end{array}$ & $\begin{array}{r}\text { AOT }(340 \mathrm{~nm}) \\
\text { WO/W }(\%)\end{array}$ \\
\hline 5 & $82 / 90(+9)$ & $0.31 / 0.33(+8)$ & 43/47 (+9) & $17 / 19(+11)$ & $10 / 11(+10)$ & $0.80 / 0.85(+6)$ \\
\hline 6 & $104 / 114(+10)$ & $0.46 / 0.51(+11)$ & $60 / 66(+10)$ & $28 / 31(+11)$ & $12 / 14(+17)$ & $1.20 / 1.30(+8)$ \\
\hline 7 & $147 / 189(+29)$ & $0.81 / 1.0(+26)$ & $69 / 99(+43)$ & $55 / 57(+4)$ & $17 / 23(+35)$ & $2.40 / 2.50(+4)$ \\
\hline 8 & $256 / 322(+26)$ & $1.13 / 1.44(+28)$ & $151 / 200(+33)$ & $64 / 64(0)$ & $34 / 44(+29)$ & $3.40 / 3.50(+3)$ \\
\hline 9 & $309 / 534(+73)$ & $1.11 / 1.79(+62)$ & $209 / 385(+84)$ & $49 / 51(+4)$ & $44 / 75(70)$ & $2.20 / 2.40(+9)$ \\
\hline 10 & 79/157 (+99) & $0.39 / 0.64(+63)$ & $34 / 94(+176)$ & $33 / 34(+3)$ & $7 / 16(+129)$ & $0.75 / 0.80(+7)$ \\
\hline 11 & $39 / 39(0)$ & $0.31 / 0.33(+6)$ & $3.04 / 3.52(+16)$ & $29 / 29(0)$ & $2.34 / 2.47(+6)$ & $0.60 / 0.65(+8)$ \\
\hline 12 & $43 / 47(+9)$ & $0.30 / 0.33(+10)$ & $3.94 / 6.21(+58)$ & $30 / 31(+3)$ & $2.48 / 2.94(+18)$ & $0.70 / 0.71(+1)$ \\
\hline
\end{tabular}

$30 \%$ over the studied period (except for the 6 and $10 \mathrm{Au}$ gust, for which the model underestimates observed values by a factor of 2 to 3 ). CHIMERE was able to reproduce the fine mode of the aerosol volume size distribution (simulated peak at $0.13 \mu \mathrm{m}^{3} \mu \mathrm{m}^{-2}$ for $r \simeq 0.1-0.3 \mu \mathrm{m}$ ) retrieved by AERONET (observed peak at $0.16 \mu \mathrm{m}^{3} \mu \mathrm{m}^{-2}$ for $r \simeq 0.2$ $0.4 \mu \mathrm{m}$ ), which led to good agreement between the modelled and observed wavelength dependence of AOT (biases less than $35 \%$ in the visible/near-infrared wavelengths). In addition, the model was shown to reproduce the low absorbing efficiency of the aerosol plume (dominated by primary organic species) with modelled elevated SSA ( 0.97 between 300 and $1000 \mathrm{~nm}$ ) close to AERONET values over Moscow (0.95- 0.96 between 440 and $1020 \mathrm{~nm})$.

In a second simulation, modelled aerosol optical properties have been used in WRF to investigate their direct radiative impacts. During this major fire event, important shortwave aerosol direct radiative forcings have been simulated at the surface $\left(-(10-150) \mathrm{W} \mathrm{m}^{-2}\right.$ in diurnal averages) throughout eastern Europe. Maximum ADRF values of -80 to $-150 \mathrm{~W} \mathrm{~m}^{-2}$ have been obtained over areas under the influence of the aerosol plume. On a regional scale, the impact of this shortwave ADRF on the simulated near-surface air temperature was non-negligible, with a reduction from 0.2 to $2.6^{\circ}$ (in diurnal averages) over a large part of the domain. Moscow has been subjected to an important aerosol radiative effect, especially during the arrival of the aerosol plume between 6 and 10 August. Simulations indicated that the presence of the aerosol plume over this area caused a significant reduction of shortwave solar radiation reaching the surface (up to $70-84 \mathrm{~W} \mathrm{~m}^{-2}$ in diurnal averages) with a small part $(20-30 \%)$ due to solar absorption within the atmospheric layer. Including the feedback of the ADRF induced a decrease of the near-surface air temperature (in diurnal averages) from 0.5 to $1.6^{\circ}$ for Moscow and from 0.5 to $1.0^{\circ}$ for Nizhny, which leads to a better agreement with observations. This aerosol cooling effect has been shown to occur over the whole boundary layer and contribute to stabilize it with a reduction of the ABL height in presence of aerosols of 13 to
$65 \%$ during daytime. This decrease was the result of a loss of air entrainment as the vertical wind speed in the ABL was shown to be reduced by 5 to $80 \%$ (at midday), compared to the simulation without aerosols. However, the shortwave ADRF has a lower impact on the horizontal wind speed with a reduction of only $0.05-0.86 \mathrm{~m} \mathrm{~s}^{-1}(1-25 \%)$ simulated over Moscow during 8 August, suggesting that the dilution of particles would be mainly affected by the weakening of the ABL development and associated vertical wind speed with some consequences on the surface particulate pollution.

Indeed, a CHIMERE sensitivity test, driven by the WRF meteorological fields including the ADRF feedback, predicted a large increase (up to $99 \%$ ) in the near-surface $\mathrm{PM}_{10}$ concentrations due to the lower vertical dilution. As a result, biases with the $\mathrm{PM}_{10}$ concentrations observed over Moscow during this specific period have been reduced. However, the aerosol direct radiative effect on ABL ventilation is not the only factor that could influence particulate pollution. Alteration of photolysis rates by the aerosol solar extinction could affect the formation of secondary species and hence the concentration of particles. This last point will be investigated in a future study by using a complete online coupling between CHIMERE and the Tropospheric Ultraviolet and Visible Radiation Model.

\subsection{Concluding remarks}

An important characteristic of the 2010 Russian fires is their high solar scattering efficiency. Elevated SSA values (0.950.96 in the visible spectrum) have been already observed over the same region by Chubarova et al. (2011) during the 2002 fire event and could be explained by smoldering conditions (Chubarova et al., 2011, 2012). Such SSA are however higher than values measured for smoke aerosols at other locations. For example, Calvo et al. (2010) obtained a mean SSA of 0.87 (at $440 \mathrm{~nm}$ ) during a fire episode that occurred over Spain during September 2000. Moreover, a moderate aerosol solar absorption has been measured by Gyawali et al. (2009) (SSA $=0.88-0.93$ at $405 \mathrm{~nm}$ ) during 
the 2008 summer California wildfires. In numerous cases, the direct radiative forcing of biomass-burning aerosols induces significant changes in the atmospheric dynamics at regional scale (Vendrasco et al., 2009; Ott et al., 2010; Randles and Ramaswamy, 2010; Tummon et al., 2010; Turquety, 2013). For example, Randles and Ramaswamy (2010) and Tummon et al. (2010) showed that the atmospheric heating due to absorbing smoke particles associated with the aerosol-induced surface cooling tend to stabilize the lower troposphere over southern Africa. It is interesting to note that, in our study, even a moderate atmospheric radiative shortwave heating due to very low absorbing smoke aerosols is also favourable to a stabilization of the atmospheric boundary layer. This result is coherent with the modelling sensitivity study performed by Randles and Ramaswamy (2010) indicating that the response of the southern African regional climate to the direct radiative forcing of scattering aerosols could be non-negligible.

In turn, we showed that the lowering of the ABL development due to the ADRF could favour the accumulation of pollutants near the surface. However, the atmospheric shortwave heating induced by absorbing smoke particles could affect the atmospheric circulation and the transport of particles in a different way, over certain regions such as the tropics (Ott et al., 2010) or the equatorial region (Tummon et al., 2010). For instance, Ott et al. (2010) highlighted that the aerosol solar absorption was shown to induce an elevated heat pump mechanism, enhancing the vertical motion and the transport of $\mathrm{CO}$, produced by the Indonesian biomass-burnings, from the low troposphere to the tropopause and the stratosphere. The ADRF by smoke particles is also found to affect the precipitation regime and thus aerosol scavenging. It could result in either an intensification or a reduction of precipitation in function of the aerosol-induced changes in the air temperature gradient and low-level horizontal pressure (Vendrasco et al., 2009; Tummon et al., 2010).

The above-mentioned studies, using measurements and modelling experiments, emphasize the great complexity and variety of the atmosphere response to the biomass-burning direct radiative forcing. Indeed, not all study results agree on the magnitude and patterns of the feedbacks, which is a motivation to continue efforts in the characterization and understanding of the wildfires radiative impacts.

Acknowledgements. The authors are grateful to the CRI at Lille 1 for its technical support. This work was partly funded by the French ministry in charge of ecology and the PRIMEQUAL program (APIFLAME). We also acknowledge the University of Wyoming for providing us the meteorological data. Anthony Ung (INERIS) is acknowledged for his help in processing the fire-emissions data.

Edited by: D. Spracklen

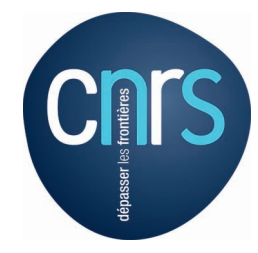

The publication of this article is financed by CNRS-INSU.

\section{References}

Bessagnet, B., Hodzic, A., Vautard, R., Beekmann, M., Cheinet, S., Honoré, C., Liousse, C., and Rouil, L.: Aerosol modeling with CHIMERE-Preliminary evaluation at the continental scale, Atmos. Environ., 38, 2803-2817, 2004

Bessagnet, B., Menut, L., Curci, G., Hodzic, A., Guillaume, B., Liousse, C., Moukhtar, S., Pun, B., Seigneur, C., and Schulz, M.: Regional modeling of carbonaceous aerosols over Europe-Focus on secondary organic aerosols, J. Atmos. Chem., 61, 175-202, 2009.

Bréon, F. M. and Colzy, S.: Cloud detection from the spaceborne POLDER instrument and validation against surface synoptic observations, J. Appl. Meteorol., 36, 777-785, 1999.

Calvo, A. I., Pont, V., Castro, A., Mallet, M., Palencia, C., Roger, J. C., Dubuisson, P., and Fraile, R.: Radiative forcing of haze during a forest fire in Spain, J. Geophys. Res., 115, d08206, doi:10.1029/2009JD012172, 2010.

Carslaw, K. S., Boucher, O., Spracklen, D. V., Mann, G. W., Rae, J. G. L., Woodward, S., and Kulmala, M.: A review of natural aerosol interactions and feedbacks within the Earth system, Atmos. Chem. Phys., 10, 1701-1737, doi:10.5194/acp-10-17012010, 2010.

Chen, F. and Dudhia, J.: Coupling an advanced landsurface/hydrology model with the Penn State/NCAR MM5 modeling system. Part 1: Model description and implementation, Mon. Weather Rev., 129, 569-585, 2001.

Chou, M. D. and Suarez, M. J.: An efficient thermal infrared radiation parametrization for use in general circulation models, NASA. Tech. Memo., 3, tM-104606, 85 pp., 1994.

Chubarova, N., Gorbarenko, E., Nezval, I., and Shilovtseva, O.: Aerosol and radiation characteristics of the atmosphere during forest and peat fires in 1972, 2002 and 2010 in the region of Moscow, J. Atmos. Ocean. Phys., 47, 729-738, 2011.

Chubarova, N., Nezval, Ye., Sviridenkov, I., Smirnov, A., and Slutsker, I.: Smoke aerosol and its radiative effects during extreme fire event over Central Russia in summer 2010, Atmos. Meas. Tech., 5, 557-568, doi:10.5194/amt-5-557-2012, 2012.

d'Almeida, G. A., Koepke, P., and Shettle, E. P.: Atmospheric aerosols: Global climatology and radiative characteristics, edited by: Deepak, A., 1991.

Déandreis, C., Balkanski, Y., Dufresne, J. L., and Cozic, A.: Radiative forcing estimates of sulfate aerosol in coupled climatechemistry models with emphasis on the role of the temporal variability, Atmos. Chem. Phys., 12, 5583-5602, doi:10.5194/acp12-5583-2012, 2012.

Deuzé, J. L., Bréon, F. M., Devaux, C., Goloub, P., Herman, M., Lafrance, B., Maignan, F., Marchand, A., Nadal, F., Perry, G., and Tanré, D.: Remote sensing of aerosols over land surface from POLDER-ADEOS-1 polarized measurements, J. Geophys. Res., 106, 4913-4926, 2001. 
Dubovik, O., Smirnov, A., Holben, B., King, M., Kaufman, Y., Eck, T., and Slutsker, I.: Accuracy assessments of aerosol optical properties retrieved from Aerosol Robotic Network (AERONET) Sun and sky radiance measurements, J. Geophys. Res., 105, 9791-9806, 2000.

Dubovik, O., Herman, M., Holdak, A., Lapyonok, T., Tanré, D., Deuzé, J. L., Ducos, F., Sinyuk, A., and Lopatin, A.: Statistically optimized inversion algorithm for enhanced retrieval of aerosol properties from spectral multi-angle polarimetric satellite observations, Atmos. Meas. Tech., 4, 975-1018, doi:10.5194/amt-4975-2011, 2011.

Fast, J. D., Gustafson, W. I., Easter, R. C., Zaveri, R. A., Barnard, J. C., Chapman, E. G., Grell, G. A., and Peckham, S. E.: Evolution of ozone, particulates, and aerosol direct radiative forcing in the vicinity of Houston using a fully coupled meteorology-chemistry-aerosol model, J. Geophys. Res., 111, d21305, doi:10.1029/2005JD006721, 2006.

Filippi, J. B., Bosseur, F., Mari, C., Lac, C., Moigne, P. L., Cuenot, B., Veynante, D., Cariolle, D., and Balbi, J. H.: Coupled atmosphere-wildland fire modelling, J. Adv. Model. Earth Syst., 1, 11, doi:10.3894/JAMES.2009.1.11, 2009.

Forster, P., Ramaswamy, V., Artaxo, P., Berntsen, T., Betts, R., Fahey, D. W., Haywood, J., Lean, J., Lowe, D. C., Myhre, G., Nganga, J., Prinn, R., Raga, G., Schulz, M., and Dorland, R. V.: Changes in atmospheric constituents and in radiative forcing, in: Climate Change 2007: the physical science basis, Contribution of working group I to the fourth assessment report of the Intergovernmental Panel on Climate Change, edited by: S., Solomon, Qin, D., Manning, M., Chen, Z., Marquis, M., Averyt, K.B., Tignor, M., and Miller, H. L., IPCC report, 2007.

Fu, J. S., Hsu, N. C., Gao, Y., Huang, K., Li, C., Lin, N.-H., and Tsay, S.-C.: Evaluating the influences of biomass burning during 2006 BASE-ASIA: a regional chemical transport modeling, Atmos. Chem. Phys., 12, 3837-3855, doi:10.5194/acp-12-38372012, 2012.

Guenther, A., Karl, T., Harley, P., Wiedinmyer, C., Palmer, P. I., and Geron, C.: Estimates of global terrestrial isoprene emissions using MEGAN (Model of Emissions of Gases and Aerosols from Nature), Atmos. Chem. Phys., 6, 3181-3210, doi:10.5194/acp-63181-2006, 2006.

Gyawali, M., Arnott, W. P., Lewis, K., and Moosmüller, H.: In situ aerosol optics in Reno, NV, USA during and after the summer 2008 California wildfires and the influence of absorbing and non-absorbing organic coatings on spectral light absorption, Atmos. Chem. Phys., 9, 8007-8015, doi:10.5194/acp-9-8007-2009, 2009.

Hess, M., Koepke, P., and Schult, I.: Optical properties of aerosols and clouds: The software package OPAC, B. Am. Meteorol. Soc., 79, 831-844, 1998.

Hodzic, A., Madronich, S., Bohn, B., Massie, S., Menut, L., and Wiedinmyer, C.: Wildfire particulate matter in Europe during summer 2003: meso-scale modeling of smoke emissions, transport and radiative effects, Atmos. Chem. Phys., 7, 4043-4064, doi:10.5194/acp-7-4043-2007, 2007.

Holben, B., Eck, T., Slutsker, I., Tanré, D., Buis, J., Setzer, A., Vermote, E., Reagan, J., Kaufman, Y., Nakajima, T., Lavenu, F., Jankowiak, I., and Smirnov, A.: AERONET: a federated instrument network and data archive for aerosol characterization, Remote Sens. Environ., 66, 1-16, 1998.
Hong, S. Y.: Stable boundary layer mixing in a vertical diffusion scheme, paper presented at the Korea Meteorological Society fall conference Seoul, 25-26 October, 2007.

Hong, S. Y., Noh, Y., and Dudhia, J.: A new vertical diffusion package with an explicit treatment of entrainment processes, Mon. Weather Rev., 134, 2318-2341, 2006.

Junker, C. and Liousse, C.: A global emission inventory of carbonaceous aerosol from historic records of fossil fuel and biofuel consumption for the period 1860-1997, Atmos. Chem. Phys., 8, 1195-1207, doi:10.5194/acp-8-1195-2008, 2008.

Kain, J. S.: The Kain-Fritsch convective parametrization: An update, J. Appl. Meteorol., 43, 170-181, 2004.

Kaiser, J. W., Heil, A., Andreae, M. O., Benedetti, A., Chubarova, N., Jones, L., Morcrette, J.-J., Razinger, M., Schultz, M. G., Suttie, M., and van der Werf, G. R.: Biomass burning emissions estimated with a global fire assimilation system based on observed fire radiative power, Biogeosciences, 9, 527-554, doi:10.5194/bg-9-527-2012, 2012.

Konovalov, I. B., Beekmann, M., Kuznetsova, I. N., Yurova, A., and Zvyagintsev, A. M.: Atmospheric impacts of the 2010 Russian wildfires: integrating modelling and measurements of an extreme air pollution episode in the Moscow region, Atmos. Chem. Phys., 11, 10031-10056, doi:10.5194/acp-11-10031-2011, 2011.

Krekov, G. M.: Aerosols effects on climate, University of Arizona Press, Tucson, 1993.

Malavelle, F., Pont, V., Mallet, M., Solmon, F., Johnson, B., Leon, J. F., and Liousse, C.: Simulation of aerosol radiative effects over West Africa during DABEX and AMMA SOP-0, J. Geophys. Res., 116, d08205, doi:10.1029/2010JD014829, 2011.

Marley, N. A., Gaffney, J. S., Baird, J. C., Blazer, C. A., Drayton, P. J., and Frederick, J. E.: An empirical method for the determination of the complex refractive index of size-fractionated atmospheric aerosols for radiative transfer calculations, Aerosol Sci. Tech., 34, 535-549, 2001.

Martins, V., Miranda, A. I., Carvalho, A., Schaap, M., Borrego, C., and Sa, E.: Impact of forest fires on particulate matter and ozone levels during the 2003, 2004 and 2005 fire seasons in Portugal, Sci. Total Environ., 414, 53-62, 2012.

Mashayekhi, R., Irannejad, P., Feichter, J., and Bidokhti, A. A.: Implementation of a new aerosol HAM model within the Weather Research and Forecasting (WRF) modeling system, Geosci. Model Dev. Discuss., 2, 681-707, doi:10.5194/gmdd-2-6812009, 2009.

Menut, L., Tripathi, O. M., Colette, A., Vautard, R., Flaounas, E., and Bessagnet, B.: Evaluation of regional climate simulations for air quality modelling purposes, Clim. Dynam., 40, 2515-2533, doi:10.1007/s00382-012-1345-9, 2012.

Menut, L., Bessagnet, B., Khvorostyanov, D., Beekmann, M., Blond, N., Colette, A., Coll, I., Curci, G., Foret, G., Hodzic, A., Mailler, S., Meleux, F., Monge, J.-L., Pison, I., Siour, G., Turquety, S., Valari, M., Vautard, R., and Vivanco, M. G.: CHIMERE 2013: a model for regional atmospheric composition modelling, Geosci. Model Dev., 6, 981-1028, doi:10.5194/gmd6-981-2013, 2013.

Mlawer, E., Taubman, S., Brown, P., Iacono, M., and Clough, S.: Radiative transfer for inhomogeneous atmospheres: RRTM, a validated correlated-K model for the longwave, J. Geophys. Res., 102, 16633-16682, 1997. 
Moritz, M. A., Parisien, M.-A., Batllori, E., Krawchuk, M. A., Dorn, J. V., Ganz, D. J., and Hayhoe, K.: Climate change and disruptions to global fire activity, Ecosphere, 3, 49, doi:10.1890/ES1100345.1, 2012.

Ott, L., Duncan, B., Pawson, S., Colarco, P., Chin, M., Randles, C., Diehl, T., and Nielsen, E.: Influence of the 2006 Indonesian biomass burning aerosols on tropical dynamics studied with the GEOS-5 AGCM, J. Geophys. Res., 115, d14121, doi:10.1029/2009JD013181, 2010.

Péré, J. C., Mallet, M., Bessagnet, B., and Pont, V.: Evidence of the aerosol core-shell mixing state over Europe during the heat wave of summer 2003 by using CHIMERE simulations and AERONET inversions, Geophys. Res. Lett., 36, doi:10.1029/2009GL037334, 2009.

Péré, J. C., Mallet, M., Pont, V., and Bessagnet, B.: Evaluation of an aerosol optical scheme in the chemistry-transport model CHIMERE, Atmos. Environ., 44, 3688-3699, 2010.

Péré, J. C., Mallet, M., Pont, V., and Bessagnet, B.: Impact of aerosol direct radiative forcing on the radiative budget, surface heat fluxes, and atmospheric dynamics during the heat wave of summer 2003 over western Europe: A modeling study, J. Geophys. Res., 116, d23119, doi:10.1029/2011JD016240, 2011.

Pun, B., Seigneur, C., and Lohman, K.: Modeling secondary organic aerosol via multiphase partitioning with molecular data, Environ. Sci. Technol., 40, 4722-4731, 2006.

Ramanathan, V. and Feng, Y.: Air pollution, greenhouse gases and climate change: global and regional perspectives, Atmos. Environ., 43, 37-50, 2009.

Randles, C. A. and Ramaswamy, V.: Direct and semi-direct impacts of absorbing biomass burning aerosol on the climate of southern Africa: a Geophysical Fluid Dynamics Laboratory GCM sensitivity study, Atmos. Chem. Phys., 10, 9819-9831, doi:10.5194/acp-10-9819-2010, 2010.

Skamarock, W. C., Klemp, J. B., and Dudhia, J.: Prototypes for the WRF (Weather Research and Forecasting) model, paper presented at the ninth conference on mesoscale processes, A. Meteorol. Soc., Fort Lauderdale, Florida, 2001.

Strada, S., Mari, C., Filippi, J. B., and Bosseur, F.: Wildfire and the atmosphere: modelling the chemical and dynamic interactions at the regional scale, Atmos. Environ., 51, 234-249, 2012.

Tanré, D., Bréon, F. M., Deuzé, J. L., Dubovik, O., Ducos, F., François, P., Goloub, P., Herman, M., Lifermann, A., and Waquet, F.: Remote sensing of aerosols by using polarized, directional and spectral measurements within the A-Train: the PARASOL mission, Atmos. Meas. Tech., 4, 1383-1395, doi:10.5194/amt-4-1383-2011, 2011.
Tummon, F., Solmon, F., Liousse, C., and Tadross, M.: Simulation of the direct and semidirect aerosol effects on the southern Africa regional climate during the biomass burning season, J. Geophys. Res., 115, d19206, doi:10.1029/2009JD013738, 2010.

Turquety, S.: Fire Phenomena and the Earth System: An Interdisciplinary Guide to Fire Science, Wiley Blackwell, 2013.

Vautard, R., Bessagnet, B., Chin, M., and Menut, L.: On the contribution of natural aeolian sources to particulate matter concentrations in Europe: Testing hypotheses with a modelling approach, Atmos. Environ., 39, 3291-3303, 2005.

Vendrasco, E. P., Dias, P. L. S., and Freitas, E. D.: A case study of the direct radiative effect of biomass burning aerosols on precipitation in the Eastern Amazon, Atmos. Res., 94, 409-421, 2009.

Waquet, F., Cornet, C., Deuzé, J.-L., Dubovik, O., Ducos, F., Goloub, P., Herman, M., Lapyonok, T., Labonnote, L. C., Riedi, J., Tanré, D., Thieuleux, F., and Vanbauce, C.: Retrieval of aerosol microphysical and optical properties above liquid clouds from POLDER/PARASOL polarization measurements, Atmos. Meas. Tech., 6, 991-1016, doi:10.5194/amt-6-991-2013, 2013.

Winker, D. M., Vaughan, M. A., Omar, A., Hu, Y., Powell, K. A., Liu, Z., Hunt, W. H., and Young, S. A.: Overview of the CALIPSO mission and CALIOP data processing algorithms, J. Atmos. Ocean. Tech., 26, 2310-2323, 2009.

Witte, J. C., Douglass, A. R., da Silva, A., Torres, O., Levy, R., and Duncan, B. N.: NASA A-Train and Terra observations of the 2010 Russian wildfires, Atmos. Chem. Phys., 11, 9287-9301, doi:10.5194/acp-11-9287-2011, 2011.

Wong, D. C., Pleim, J., Mathur, R., Binkowski, F., Otte, T., Gilliam, R., Pouliot, G., Xiu, A., Young, J. O., and Kang, D.: WRFCMAQ two-way coupled system with aerosol feedback: software development and preliminary results, Geosci. Model Dev., 5, 299-312, doi:10.5194/gmd-5-299-2012, 2012.

Zanis, P.: A study on the direct effect of anthropogenic aerosols on near surface air temperature over Southeastern Europe during summer 2000 based on regional climate modeling, Ann. Geophys., 27, 3977-3988, doi:10.5194/angeo-27-3977-2009, 2009.

Zhang, Y., Fu, R., Yu, H., Qian, Y., Dickinson, R., Dias, M. A. F. S., Dias, P. L. D. S., and Fernandes, K.: Impact of biomass burning aerosol on the monsoon circulation transition over Amazonia, Geophys. Res. Lett., 36, 110814, doi:10.1029/2009GL037180, 2009.

Zhang, Y., Sartelet, K., Zhu, S., Wang, W., Wu, S.-Y., Zhang, X., Wang, K., Tran, P., Seigneur, C., and Wang, Z.-F.: Application of WRF/Chem-MADRID and WRF/Polyphemus in Europe - Part 2: Evaluation of chemical concentrations and sensitivity simulations, Atmos. Chem. Phys., 13, 6845-6875, doi:10.5194/acp-136845-2013, 2013. 